\title{
Autosomal recessive brachyolmia
}

INSERM

\section{Source}

INSERM. (1999). Orphanet: an online rare disease and orphan drug data base. Autosomal recessive brachyolmia. ORPHA:448242

Brachyolmia, recessive type is a form of brachyolmia (see this term), a group of rare genetic skeletal disorders, characterized by short-trunked short stature with platyspondyly and scoliosis. Corneal opacities and precocious calcification of the costal cartilage are rare syndromic components. Premature pubarche may occur. 